\title{
Tanulmány
}

\section{AZ 1968-AS MECHANIZMUSREFORM ÉS GAZDASÁGI JOGUNK ÁTALAKULÁSA}

\section{THE 1968 REFORM OF THE ECONOMIC MECHANISM AND THE TRANSFORMATION OF THE HUNGARIAN LEGAL SYSTEM}

\author{
Verebics János \\ PhD, egyetemi docens, Eötvös Loránd Tudományegyetem, Gazdálkodástudományi Intézet \\ verebics@gmail.com
}

\begin{abstract}
ÖSSZEFOGLALÁS
Az ötven évvel ezelőtt, 1968. január 1-jén indult magyar mechanizmusreform alapgondolatát "a népgazdaság tervszerű központi irányításának és az áruviszonyok, a piac aktív szerepének szerves összekapcsolása" jelentette. A korábbi, direkt tervutasításos rendszert (melyben a vállalatok feladata lényegében sajátos államigazgatási szervként a terv végrehajtása volt, $\mathrm{s}$ ahol a termékforgalom polgári jogi intézményei, a szerződések igen kevés szerepet kaptak) a vállalati önállóság és a szerződési kapcsolatok szabadsága váltotta fel. Az új mechanizmus „szabályozott piacgazdaságában" a gazdasági folyamatok legfőbb koordinációs eszköze továbbra a népgazdasági terv maradt, mely azonban már nem közvetlenül érvényesült, hanem a gazdaságpolitikát megvalósító jogi szabályozás révén. Az 1967-1972 között született közel kétezer jogszabály a gazdaságra vonatkozó joganyagot szinte teljeskörűen újraszabályozta, de a jogalkotási folyamat a reform 1972-es lelassulása után is folytatódott: a hetvenes évek végén a Polgári Törvénykönyv átfogó felülvizsgálatával, a termékforgalom újraszabályozásával, az állami vállalatokról szóló törvény megalkotásával teljesedett ki. Ennek az igen átfogó, a gazdasági élet minden szegmensére kiterjedő joganyagnak gyakorlati szempontú feldolgozására, rendszerezésére először a jogirodalom vállalkozott, majd gazdaságirányítási és vállalati jog névvel új diszciplína is született. 1985-re ezekre alapozva alakult ki a "népgazdaság egészének jogát" tárgyaló gazdasági jog, mely nemcsak a politikai rendszerváltást megelőző és előkészítő gazdasági rendszerváltásban (társasági törvény, 1988) játszott kiemelkedő szerepet, hanem a magyar jogalkotásban, jogtudományban, gazdasági és jogi oktatásban máig élő, új szemléletet is meghonosított.
\end{abstract}

\section{ABSTRACT}

The basic idea of the new Hungarian economic mechanism, have been launched 50 years ago, on the $1^{\text {st }}$ of January 1968, purported a closer connection between the centralized planned economy and the goods along with a somewhat active role of the market itself. The direct command 
planned system of the time was replaced by the relative autonomy of the companies and the freedom of contracts. (The planned economy was built on the companies behaving as state administration bodies that strictly executed the national economic plans without applying the civil law institutions, i.e. contractual solutions.) Although the national economic plan remained the main coordination source in the "regulated market economy" of the new mechanism too, dirigisme was not direct anymore, and the economic policy was carried out through legal norms, regulations, rather than instructions. The nearly 2.000 legal norms, issued between 1967-1972, regulated now the laws on economy. This reregulation proceeded even after the reform had slowed down in 1972, and at the end of the 1970's this included even a general scrutiny of the Civil Code, the rewriting of the rules on product trading, marketing, and the establishing of new rules on state companies. A general but practical overview of these laws on all parts of the economy has been elaborated by the legal academic professionals, and new disciplines were born: the management of the economy and the company law. These new laws on economy emerged from the "law of the peoples' economy" providing not only a possible path to the political changes but served as the precursors of the legal changes (Companies Act, 1988), and later as the foundations of the contemporary business law as well.

Kulcsszavak: tervutasításos rendszer, gazdasági mechanizmus, 1968-as mechanizmusreform, népgazdasági terv, szabályozórendszer, szocialista gazdasági szabályozás, szocialista gazdaságirányítás, gazdasági szabályozók, tervszerű gazdasági irányítás, irányított piacgazdaság

Keywords: system of plan instructions; economic mechanism; the 1968 reform of the economic mechanism, reform of economic control and management; national economic plan system of regulators; economic management; economic regulators; planned economic management; a market system regulated by the socialist state

Az MSZMP KB 1966. május 25-27-i ülése után kiadott határozata szerint az 1968. január 1-től elindult új gazdasági mechanizmus legfontosabb alapgondolatát ,a népgazdaság tervszerü központi irányításának és az áruviszonyok, a piac aktív szerepének szerves összekapcsolása jelentette" - a szocialista tulajdon alapján. A határozat szerint a tervezés és a piac szerves egységét úgy kellett kialakítani, hogy a piac müködési feltételeit és szabályait a népgazdasági tervben összehangolt döntések határozzák meg. A piac ebben a felfogásában semmiképp nem lehetett magára hagyott, szabadversenyes piac, hanem olyan piacnak kellett lennie, ,amely úgy szabályoz, hogy ő maga is központilag szabályozva van, s ezáltal elősegíti a megalapozott népgazdasági tervek megvalósulását”. A piac ,,aktív szerepének kibontakoztatása" pedig megkívánta, hogy a termékgazdálkodás nehézkes, bürokratikus rendszerét, a termékek hatósági elosztását a kereskedelem váltsa fel (MSZMP, 1966, 14-15.).

Ezt a reformkoncepció kidolgozói mindenekelőtt a vállalati önállóság kiterjesztésével és a szerződési kapcsolatok felszabadításával kívánták elérni. Az első 
körben ez az arról való szabad döntés lehetőségének megteremtését jelentette, hogy tevékenységi körükön belül miből mennyit gyártanak és kínálnak eladásra, illetve pénzükért milyen mennyiségben, mely vállalatoktól kívánják a számukra szükséges termelőeszközöket megvásárolni. A második körben pedig annak lehetôvé tételét, hogy a termelö és felhasználó vállalatok szabadon létesíthessenek egymással közvetlen kereskedelmi, illetve kooperációs kapcsolatokat, s a külön kereskedelmi vállalatok közbeiktatása csak a gazdasági észszerüség alapján történjen, a vállalatok a náluk jelentkező kereslet túlnyomó részét raktárról elégítsék ki, az eladók és vevők szabadon állapodhassanak meg a szállítási feltételekben, $\mathrm{s}$ az állami árszabályozás keretei között az árakban is, a vevők - a népgazdasági érdek diktálta korlátokon belül - választhassanak a hazai és importáru, a gyártók-eladók pedig a hazai vagy az exportra történő értékesítés között. Legalapvetőbben ez volt a szabályozott piacgazdaság koncepciója, melyre a tervutasításos, direkt irányításon alapuló gazdaságirányítási rendszerről 1968 után Magyarországnak fokozatosan kellett volna áttérnie.

1963-1964 körül az európai KGST (Kölcsönös Gazdasági Segítség Tanácsa) -országok mindegyikének szembe kellett néznie a tervutasításos rendszer fenntarthatatlanságának kérdésével. Ahogy Tímár Mátyás 1973-ban írja, a reform iránti igények szinte egy időben jelentkeztek, és fö motiváló tényezőik a gazdaságfejlődési problémák voltak (Tímár, 1973, 44.). Korrekciókra mindenütt sor került, ezek iránya és mélysége azonban igen eltérő volt, s a tervutasításos rendszer (mint a gazdaságirányítás fő eszköze) fenntartása mellett korlátozott (termelői) árreformban, a döntési szintek elhatárolásában, a vállalatok anyagi érdekeltségének fokozásában stb. jelent meg. A hatvanas évek derekáig ezen az úton járt Magyarország is.

Az ötvenes évek „kudarcba fulladt gazdaság- és társadalompolitikájával szemben" új szellemü és nagyon sok tekintetben pozitív fejlődést hozó politika és gyakorlat vált jellemzővé, melynek fő vonásait - a gazdaságpolitikai prioritások megváltoztatásával - a második hároméves terv időszakában (1958-1960) fogalmazták meg. Ez az új gazdaságpolitika a korabeli megfogalmazás szerint mindenekelött az életszínvonal emelkedését tekintette alapvető célnak: ennek jegyében s viszonylag kedvezö külgazdasági körülmények között fogtak neki az iparstruktúra átalakításának, a müszeripar, híradástechnika, erősáramú gépgyártás, szerszámgépgyártás, dízelmotorgyártás stb. fejlesztésének, s kapott jelentős támogatást a vegyipari és élelmiszeripari termékek gyártása. Gyors fellendülés vette kezdetét a gyógyszeriparban, valamint több évtizedes lemaradás után elindult az infrastruktúra (lakásépítési program, közlekedési hálózat, autópályák, dízelesítés, metró) fejlesztése. Ezzel párhuzamosan zajlott, s zárult le 1961-re a mezőgazdaság átalakítása, ,a falu szövetkezeti átszervezése”, az ennek nyomán „feleslegessé vált" munkaerőt (1961-1965 között mintegy 460000 főt) az ipar „,vette fel”. 
Az 1961-1965 közötti időszak gazdasági fejlődése mindazonáltal összességében mégsem érte el a tervezett ütemet: bár az iparban a termelés 46\%-kal lett nagyobb, az amúgy is kiugróan magas termelési költségek a tervezetthez képest 15\%-kal növekedtek, s elmaradt a termelékenység várt növekedése is. Az életszínvonal növelésével összefüggő célok ugyan megvalósultak, a reáljövedelem nem csökkent (igaz, az 1957 utáni gyakorlattal szakítva érdemben nem is növekedett) - ezt azonban csak a külkereskedelmi passzívum jelentős növekedése árán sikerült megvalósítani. E változások úgy a reform előkészítésének időszakában, mint bevezetése után, de a kései magyar szocializmus önfelfogásában is szükségszerü, elkerülhetetlen lépésként jelentkeztek, s elsősorban a „továbbfejlődés akadályozójává vált” - központi anyag- és termelőeszköz-elosztásra épülő - tervutasításos rendszer meghaladását jelentették, de a „szövetkezeti tulajdon egyenértékesítését” és a magánkezdeményezés számára való „tág tér” megnyitását is, természetesen bizonyos, fennmaradó politikai korlátok között.

A különböző korszakokban született értékelések abban is egyetértenek, hogy a változásokat (a politikai akarat megszületését) a kényszer szülte: a direkt tervutasításos rendszer korrekciója (az 1957-től kialakuló, a vállalati érdekérvényesítésnek nagyobb teret adó „mérsékelt tervutasításos rendszer”) a súlyosbodó gazdasági problémák kezelésére többé már nem volt alkalmas: a gazdaságirányítási rendszert alapjaiban kellett átalakítani. A reform mindazonáltal a gazdaságirányítási rendszerre korlátozódott, s a gazdaságpolitika nem járt együtt az MSZMP VII. kongresszusán kitúzött, alapvető céljainak megváltoztatásával: attól a politikai vezetés a hatvanas évek elején, a második ötéves terv végrehajtásával elkezdődött kedvező folyamatok felgyorsítását s megerősítését várta. Erre való tekintettel alakították ki az 1966. évi II. törvénnyel elfogadott, a népgazdaság 1966-1970. évi fejlesztéséröl szóló harmadik ötéves tervének összességben aztán teljesített, sőt, egyes területeken lényegesen túl is teljesített irányszámait is. Ebben nem csekély szerepet játszott az 1968-as mechanizmusreform, mely azonban a korabeli felfogás szerint nem irányváltást jelentett, hanem a korábbi gazdaságpolitika folytatását más, hatékonyabbnak gondolt eszközökkel.

A pártvezetésnek a radikális változásokat hozó reform iránti elkötelezettsége ennyi év távlatából sem kérdőjelezhető meg: 1968-1969-ben maga Kádár János is igen sok alkalommal állt ki a reform szükségessége és végrehajtásának igénye mellett - nemcsak a Központi Bizottság vagy a Politikai Bizottság plénumain, de munkásgyüléseken, tanácskozásokon is. Ennek csak egyik oka volt a reform elkerülhetetlenségének elfogadása - a másik a kádári konszolidáció sikerében, az államhatalom és a „,szocialista rend” megerősödésében volt kereshető. Mikor Kádár János 1969 áprilisában a szocialista brigádvezetők harmadik országos tanácskozásán maga hozza szóba a nyereségérdekeltség középpontba állításával kapcsolatos azon félelmeket, hogy ez visszakanyarodást jelenthet a kapitalizmus irányába, 
magabiztosan cáfol: ,Ez természetesen nem igaz, mert a mi reformunk: szocialista gazdaság - szocialista reformja.” (Kádár, 1982, 255.) Bár a reform bevezetése után született hivatalos értékelések a folyamatként felfogott gazdaságirányítási reform tudatosan tervezett voltát, a munkálatok és viták pártirányítás melletti lebonyolítását hangsúlyozták, s azok kezdetét következetesen már a hatvanas évek elejére vezették vissza, a reform elökészítése alapvetően a technokraták - az előmunkálatokat végző bizottságokban részt vevő kb. kétszáz közgazdász, mérnök, tudós, állami, vállalati és szövetkezeti szakember - kezében volt, akiknek a javaslata egyéves megfeszített munka után került a párt Központi Bizottsága elé, amely aztán azt határozattá emelte.

A 68-as reform - amelynek eredményeire a pártvezetés a létező szocializmus idején sosem szünt meg hivatkozni, s a saját gazdaságpolitikai korrekciós intézkedéseit ennek folytatásaként beállítani - a hetvenes évek elején megtorpant ugyan, de így is messzire jutott. A mechanizmusreform hozta változások, emelte ki Vékás Lajos közel két évtizednyi távolságból visszapillantva, mindenképpen azt jelentették, hogy az áru- és pénzviszonyok az állami tulajdon területén is aktív szerephez jutottak, ,a gazdaságirányítás felszínre hozta, kiterjesztette és felerősítette az áruviszonyok hatáskörét" (Vékás, 1986, 19.). A reform - minden ellentmondásossága, hibája és befejezetlen volta ellenére - a magyar gazdaságtörténet talán legsikeresebb, az ipari termelés és a GDP 1968-1978 közötti 77\%-os növekedésével járó, Stark Antal által 2009-ben ,aranykornak” nevezett (Stark, 2009, 13.) évtizedének kezdetét jelentette: lebontotta a tervutasításos gazdaságirányítási rendszert, dinamizálta a gazdaságot, felszabadította a szerződéses kapcsolatokat, s utat nyitott a vállalkozás új jogi formáinak megjelenése elött is. Sajátos módon hatása legtartósabban talán épp a gazdaság jogi szabályozása területén érvényesült, ahol a fejlődés a reform megtorpanása után is folytatódott.

A szállítási szerződésekről szóló 10/1966 (II. 14.) Korm. sz. rendelet az első reform jogszabályként 1966. február 14-én került elfogadásra. Kodifikációs igénynyel készült jogszabály volt, mely - egyelöre még a direkt tervutasításos rendszer közegével körülvéve - kilenc fejezetben, átfogóan rendezte a szerződéstípusra vonatkozó szabályokat (Harmathy, 1966). Az alapelvek körében a szerződések célját (rendeltetését), a szerződés jogi tartalmát és a felek fö kötelezettségeit rögzítette, együttmüködési kötelezettséget, s az adott helyzetben általában elvárható gondosság tanúsításának kötelezettségét írta elö, önálló fejezetben szabályozta a szerződéskötéssel és a szerződés tartalmával összefüggő kérdéseket, a szerződés módosítása és megszünése problémáját. Részletekbe menően rendelkezett a teljesítésről és a szerződésszegésről, s egyes szerződésfajtákat (kapacitáslekötési szerződés, fejlesztési szerződés, bizományi szerződés, raktári szerződés) külön is szabályozott. A vegyes rendelkezések körében a mögöttes szabályok alkalmazásáról, a rendelettől való eltérés feltételeiről, a szállítási alapfeltételek megállapításáról és azoknak a jogforrási rendszerben elfoglalt helyéről, a rendelet vállalkozási szer- 
ződésekre való alkalmazhatóságáról, a záró és átmeneti rendelkezéseknél pedig a hatályba lépéssel összefüggő kérdéseket szabályozta.

A reformmal kapcsolatos átfogó jogalkotás csak a KB-határozat meghozatala (1966. május 25-27.) után, a 2012/1966. (VI. 12.) Korm. határozat szerinti tematika alapján kezdődött meg. „Viszonylag rövid idő alatt igen sok jogszabály kibocsátására volt szükség, viszonylag kiforratlan viszonyok között, rendelkezésre álló tapasztalatok nélkül. Ezek a jogszabályok továbbá nem tatarozó-javítgató jellegüek voltak, hanem a jogrendszer széles területein lényegbevágó, sok vonatkozásban - a szocialista koncepció szellemén belül maradva - megváltoztatták "törvényeink szellemét« és jogi-közgazdasági-igazgatási koncepciónk jelentős megváltozásával jártak" - bocsátotta előre az áttérés szabályainak monografikus áttekintésére 1968-ban vállalkozó Eörsi Gyula (1968, 7.). A „,szocialista koncepció szellemén belül maradás" mindenekelőtt a tulajdonviszonyok kikezdhetetlenségének rögzítését és a piac szabályozott voltát jelentette. A jogszabályok útján közvetített közgazdasági eszközök az állami költségvetés alakítására (a vállalatok és személyek jövedelmeit befolyásoló, az érdekeltség és a fogyasztási cikkek piacára kiható adóztatás, a beruházási javak piacára és a foglalkoztatási politikára közvetlenül kiható központi beruházások, az állam egyéb kiadásai), a hitel- és kamatpolitika, valamint az árpolitika (alkalmazandó, illetve alkalmazható árformák, ármozgások meghatározása, mely különösen a részpiacok szabályozásával gyakorolt közvetlen hatást), a külkereskedelmi és devizális kapcsolatok külön eszközrendszere (árfolyam-politika, szubvenciók és lefölözések rendszere, vámrendszer), s természetesen az általános és egyedi állami (vállalatok alapításával, tevékenységi körének meghatározásával, összevonásával, megszüntetésével, egyes tevékenységek engedélyezéshez kötésével, export-import joggal való felruházásával kapcsolatos) előírások, esetleg (és kivételes esetben) utasítások voltak a piaci szabályozás lehetséges eszközei.

Az új mechanizmusban a koordináció legfőbb eszköze a népgazdasági terv, a gazdaságpolitika megtestesítője maradt. A vállalat alapvető mozgásterét a központi döntések által befolyásolt önálló vállalati terv határozta meg, amelyhez azonban kötelező utasításokat már nem kapott: azt ,,a feladatok és eszközök összehangolásának szintjén” - a népgazdasági terv figyelembevételével -, ,észszerủ gazdálkodását" és operatív müködésének megszervezését, távlati fejlesztéseit (hosszú távú terv) és középtávú terveit (műszaki fejlesztés, kapacitásbővítés, beruházások, pótlások, rekonstrukciók, felújítások) a törvényes eszközök figyelembevételével magának kellett kidolgoznia. A „törvényes eszközök” (Eörsinél: „instrumentumok”) azt a szerteágazó, alapvetően azonban néhány nagy csoportba - a népgazdasági tervezés, az árrendszer, a müszaki fejlesztés, a beruházási rendszer, a hitel- és pénzforgalom, az állami vállalatok, azok felügyelete és ellenörzése, a jövedelemszabályozás, anyagi érdekeltség, a külkereskedelem, a termékforgalmazás és a tanácsi és a költségvetési szervek gazdálkodása - sorol- 
ható határozatokat jelentették, melyek a kormány és Gazdasági Bizottság által 1967-ben kerültek elfogadásra.

E határozatok nyomán, az Igazságügyi Minisztérium (IM) 1967 márciusában a szakmai nyilvánosság előtt is megvitatott előterjesztésére támaszkodva vette kezdetét az átfogó jogalkotási munka, melynek eredményeként kialakult a mechanizmusreform új szabályozási rendszere 1967-1968 során. Az anyag nem konkrét jogalkotási feladatokat, hanem irányelveket határozott meg (a gazdaságpolitikai irányítás jogi eszközei, a gazdaságpolitikai irányítás, a tulajdonosi jogok s hatósági jogkör kérdése, a népgazdaság központi irányításában alkalmazott terv és pénzügyi eszközök jogi szabályozása, a szerződési rendszer kiterjesztése, kockázatvállalás, felelősség, szankció, vitás jogi ügyek eldöntése, a jogi szabályozás formája). Az IM arra az álláspontra helyezkedett, hogy a gazdasági szabályozórendszer átfogó, kodifikációs szintủ újraalkotásával szemben a módosítás, kiegészítés módszerét kell követni, „még azon az áron is, ha kódexeink egy részének szerkezeti egysége sérelmet szenved" - feltétlenül szükségesnek tartotta azonban, hogy az érvényben maradó és módosított jogszabályok egységes szerkezetbe foglalva jelenjenek meg.

A Gazdasági Bizottság határozata és a Jogi Elvi Bizottság iránymutatása alapján előkészített és elfogadott jogszabályokat 1967-1969 között közel háromezer oldal terjedelmü, háromkötetes hivatalos gyüjteményben tették közzé, a jogalkotási munka következő fázisában elfogadott, a reformszabályozást számos területen (árrendszer, bérszabályozás és munkaerö-gazdálkodás, fejlesztés, forgóeszköz-gazdálkodás, termékforgalom, lakossági fogyasztás stb.) továbbfejlesztő rendelkezéseket pedig egy 1971-ben megjelent negyedik kötetben. Az ekkor született igen nagyszámú, az állam- és jogtudományok, a jogi szakma és a jogi oktatás szerepét, funkcióit, a reform utáni újragondolás igényét is felvető jogszabály legnagyobb része az új típusú (normatív, általános direktívákkal való, az adminisztratív beavatkozást már igen kivételesnek tekintő) szabályozásra törekvő közigazgatási-gazdaságirányítási jog körébe tartozott: az egyes feladatok megoldásához kapcsolódó, sok szálon futó jogalkotás eredményeként létrejövő, piacszabályozó normarendszert Eörsi „gazdasági regulátorokként” jellemezte (Eörsi, 1968, 37.).

„Tisztán” polgári jogi természetủ normának alapvetően csak a szerződési jog körébe eső kérdéseket és a jogi személyekre vonatkozó szabályokat lehetett tekinteni (és a szocialista tulajdon ezekhez kapcsolódó, ismét felmerülő problémáját), ám természetszerüleg ezek sem önmagukban jelentkeztek, hanem a gazdaságpolitikai célkitűzések komplexitásának megfelelően a termékforgalom, a gazdasági verseny, a döntőbíráskodás, a beruházások, a vállalatok és szövetkezetek müködése összefüggéseiben. Az állami vállalatokról szóló 11/1967. (V. 13.) Korm. sz. rendelet és a hozzá kapcsolódó jogszabályok szerint a vállalatok immár jogilag is nyereségérdekelt alapon múködhettek, gazdálkodásukban a vállalati érdek 
elsőbbsége érvényesült (ez az érdek azonban alapvetően nem lehet ellentétes a népgazdasági érdekkel), a rájuk bízott állami vagyont felelösen, önállósággal kezelték, a vállalati önállóságba való operatív beavatkozásnak pedig csak kivételesen, népgazdasági érdekből és szoros jogszabályi feltételek mellett lehetett helye. A 11/1967. (V. 13.) Korm. sz. rendelet azt is lehetővé tette, hogy az állami vállalatok egymással és egyéb szocialista gazdálkodó szervezetekkel (illetőleg utóbbiak egymással) tevékenységi körükkel kapcsolatos, meghatározott, közös gazdasági célok megvalósítására összefogjanak. Ennek alapvetően két útját engedte meg: azt, hogy a polgári jog szabályai szerint társuljanak, s ennek keretében egyesülést létesítsenek, s azt, hogy kereskedelmi társaság (rt., kft.) formájában közös vállalatot hozzanak létre. 1970-ben a szocialista gazdálkodó szervek társulásainak kérdéseiről külön jogszabály (az 1970. évi 19. sz. tvr.) is született.

Ez a szerteágazó, a gazdasági viszonyok egyre átfogóbb szabályozására törekvő, szinte állandóan mozgásban lévő joganyag legalapvetőbben egyrészt - államigazgatási jogi jelleggel - a gazdaságirányítással (ezen belül a gazdaságpolitikai irányító, a közvetett gazdasági szabályozórendszert meghatározó, a közhatalmi-hatósági jogosítványokkal és az állami tulajdonosi igazgatással) összefüggő kérdéseket, másrészt polgári jogi és munkajogi eszközökkel - a vállalati belső s a vállalatok közötti forgalmi viszonyokat szabályozta: utóbbi körben azonban már megjelentek olyan problémák (fogyasztóvédelem, reklám, verseny), melyek többé tisztán polgári jogi kérdésnek már aligha voltak minősíthetők. Nagy változások zajlottak le a mezőgazdaságban, a szövetkezeti szektorban is. Az önigazgatás és egyenjogúság koncepciójára építkező mezőgazdasági termelőszövetkezetekről szóló 1967. évi III. törvény és a végrehajtása tárgyában kiadott rendeletek arra törekedtek, hogy a termelőszövetkezetek müködésével és gazdálkodásával kapcsolatos kérdéseket a lehető legátfogóbb módon, részletekbe menően szabályozzák.

Még jóval a törvény hatályba lépése előtt, 1967 júniusában elfogadásra került, s hatályba is lépett a mezőgazdasági nagyüzemek gazdasági tevékenységének kiszélesítéséről szóló 18/1967. (VI. 29.) Korm. sz. rendelet s az ahhoz kapcsolódó, a mezőgazdasági nagyüzemek kiegészítő tevékenységéröl szóló 5/1967. (VIII. 3.) MÉM sz. rendelet: e két jogszabály a reformtézisek szellemében csakugyan tágra nyitotta a szövetkezetek által végezhető gazdasági tevékenység körét, s lényegében az irányított piacgazdaság vállalati jogú szereplőivé tette őket.

A törvény és végrehatási rendeletei kihirdetését követő időszakban számos további, az adózást, termékforgalmat, szerződéses és társulási viszonyokat érintő jogszabály került elfogadásra, majd 1971-ben megszületett az egységes szövetkezeti törvény (1971. évi III. törvény). A mezőgazdaságban a mechanizmusreform alapvető célkitüzései a reform indulását követő években nem változtak, az első idöszakban pedig a fő irány az üzemi, vállalatszerủ müködés, a jövedelmező gazdálkodás biztosítása maradt: ez azonban a reform szellemében a - jogszabályok által közvetített - gazdasági szabályozókon keresztül érvényesült. Mindez gyors és igen 
jelentős eredményeket hozott: a hatvanas évek elején-derekán még súlyos gondokkal küzdő magyar mezőgazdaság az ország sikerágazatává vált. A nagyüzemi/ipari termelési módszerek bevezetése, a gépesítés, az igen jelentős mértékủ mezőgazdasági beruházások éppúgy közrejátszottak a terméseredmények igen látványos növekedésében, mint az anyagi érdekeltség rendszerének átalakítása. Az árcentrikus szabályozás helyébe az adócentrikus jövedelemszabályozás lépett (1968 és 1973 között a termelőszövetkezetek által fizetett adók összege megkétszereződött); egyszerüsödött, egyes esetekben automatizmussá vált az állami támogatások rendszere. Kialakult és fö vonásaiban tartósan érvényesült a nagyüzemi gazdálkodás követelményeihez igazodó rugalmas szabályozó rendszer, s kiépült a termelőszövetkezeti alapképzés és alapgazdálkodás új rendszere is.

A gazdasággal kapcsolatos jogalkotás a reform 1972 utáni lendületének megtörése után némileg lelassult ugyan, de a hetvenes évek derekától már intenzív formában folytatódott. Megszületett a népgazdasági tervezés rendszerét szabályozó 1972. évi VII. törvény, a döntőbizottsági rendszert megszüntető s az egységes bírósági szervezetet létrehozó 1972. évi IV. törvény, a statisztikáról szóló 1973. évi V. törvény, a külkereskedelemről szóló 1974. évi III. törvény, a tervszerü devizagazdálkodásról szóló 1974. évi I. sz. törvényerejü rendelet. Újraszabályozták a beruházások rendjét, új jogterületként jelent meg a reklámszabályozás, felmerült a gazdasági verseny szabályozásának igénye (erröl törvény azonban majd csak 1984-ben születik). A Ptk. 1977-es novellája a polgári jog jelentős részét érintette, a tervszerződések kikerültek a kódexből, a kapcsolódó 7/1977. (II. 1.) MT sz. rendelettel újraszabályozták a gazdálkodó szervezetek szerződéses viszonyait. Ugyancsak 1977-ben elfogadták az állami vállalatokról szóló törvényt, más jogszabályokkal új szövetkezeti formák kerültek elismerésre, a belkereskedelemről szóló 1978. évi I. törvénnyel és a kapcsolódó rendeletekkel erős fogyasztóvédelmi intézmények alakultak ki. Kibővül a magánszemélyek által végezhető gazdasági tevékenységek (magánkisipar, magánkereskedelem) köre: a nyolcvanas évek elején - mikor a gazdaságirányítás rendje ismét átalakul - pedig már lehetővé válik a magánszemélyek gazdasági társulása is: ezt a polgári jogi társaság mintájára megalkotott gazdasági munkaközösség jelenti (1981. évi 15. tvr., 28/1981. [IX. 9.] MT. sz. rendelet).

1966 és 1978 között a magyar jogrendszer hatalmas átalakuláson ment keresztül: jóval több, mint háromezer új jogszabály lépett hatályba, a gazdaságra vonatkozó joganyag gyakorlatilag teljesen megújult. A reform nemcsak annak közgazdasági vonzatait illetően állt a közéleti érdeklődés homlokterében, de a jogászi-szakmai közvéleményt is igen erősen foglalkoztatta. A hetvenes évek végéig jelentősen továbbfejlesztett joganyag gyakorlati szempontú rendszerezését és bemutatását elöbb Kálmán György és munkaközössége (Gyarmati András, Harmathy Attila, Kabai Gyula és Szilágyi László) végezte el (Kálmán, 1979), mely az egyes jogterületeket tematikusan dolgozza fel. Az egyes fejezetek a népgazdasági 
tervezés, a gazdaságirányítás szervezete, az állami vállalat, a gazdasági társulások, a szövetkezetek, a vállalati jövedelemszabályozás és vállalati alapok, a munkaügyi szabályozás, a beruházás, a helyiséggazdálkodás, az árszabályozás, az áruforgalom igazgatása és a termékforgalom kérdéseivel foglalkoznak, de kitérnek külkereskedelem és nemzetközi gazdasági együttmüködésre, a pénz- és hitelforgalom szabályaira is. Nagy teret szentel a munka a gazdasági élet igazgatási jellegủ szankciói bemutatásának, a gazdálkodó szervezetek egymás közötti szerződéseinek általános és az egyes szerződéstípusokra vonatkozó sajátos szabályainak, az újítás, találmányok, szabadalom, mérésügy, szabványosítás kérdéseinek s az ellenőrzésnek. A vállalati jog Sárközy Tamás nevéhez köthető új elmélete már ennél lényegesen tovább lép (Sárközy, 1981). Sárközy az MTA Állam- és Jogtudományi Intézetében, Eörsi Gyula irányítása alatt dolgozva, több, a gazdaság jogi összefüggéseit vizsgáló nagymonográfia, s igen nagyszámú, szakfolyóiratokban közzétett publikáció után 1978-1979-ben jutott el - mint ő fogalmaz - „gyakorlati jogász barátaival együtt" a vállalati jog önálló koncepciójának kialakításáig (Sárközy, 2007, 152-153.).

Ez a szövetkezeti jog alapintézményeit is magában foglaló gazdaságirányítási-vállalati jogi koncepció bomlik majd ki - immár a vállalaton belüli kollektív tagsági munkaviszonyok kérdéseivel, a vállalatközi jogi kooperáció a szerződési és versenyjogot egyaránt magában foglaló megközelítésével, a felelősségi joggal, a főbb gazdasági területek komplex jogi szabályozásának feldolgozásával - egy új diszciplína (de nem új, önálló jogág) magalapozásának szándékával a budapesti és pécsi közgazdaság-tudományi egyetemek hallgatói számára készült kétkötetes, 1985-ben megjelent egyetemi tankönyv formájában (Sárközy, 1985). Ez a munka már a „népgazdaság egészének jogát” tárgyalja szisztematikusan, s azt épp a közgazdászképzés igényeire tekintettel már nem ,a jogi elméletben túlontúl is tisztelt" jogágazati tagozódás, hanem komplexen, a gazdasági mechanizmus sajátos jogi szemléletmódjában, a gazdaságpolitikai és jogi célkitűzések kölcsönös összefüggésében mutatja be.

Az ekkor megszülető gazdasági jog nem kíván alapjogágazattá válni, de igényt tart arra, hogy „keresztülfekvő, másodlagos jogágként” két pillérre alapozva elismerést nyerjen. Az első a gazdasági alkotmányjogra épülő gazdaságirányítási jog, mely az általános alkotmányjogi elveket a gazdaságra konkretizálja, s mely vertikális jogágként „túlnyomó többségben” államigazgatási jogi jellegű, pénzügyi jogi jogintézményeket tárgyal. A másik a komplex vállalati jog, mely egyaránt tárgyalja a vállalatoknak a gazdaságirányítással való vertikális kapcsolatrendszerét, a vállalatok horizontális kapcsolatait, a központi gazdaságirányítás által szabályozott piacon való fellépését, s a verseny- és kooperációs viszonyait. Ide sorolhatók - minden vállalattípusra nézve - a vállalati vezetésre és a belső mechanizmusra vonatkozó szabályai is. Ez a tág értelemben vett vállalati jog egészül ki a nem vállalati gazdálkodó alanyokra (kisipar, kiskereskedelem stb.) 
vonatkozó speciális rendelkezésekkel és a nemzetközi gazdasági kapcsolatok jogával, s indul el - még mindig vitákkal kísérve - a további fejlődés útján, ami majd 1988-ban a társasági jog és cégjog önállósulásához, később pedig teljes elismeréséhez, általános elfogadásához vezet, s igen sok szempontból napjainkig való továbbélését alapozza meg.

Azoktól az alapoktól, melyeket a 68-as mechanizmusreform lefektetett, a magyar gazdasági civiljog majd csak 1989 után szakad el, mikor a gazdasági rendszerváltást politikai rendszerváltás is követi, s az ,irányított piacgazdaság” helyébe a valódi piacgazdaság lép - de ezeket az alapokat sosem tagadja meg. Az 1968-as gazdasági reform, írja már a rendszerváltást követően, 1992-ben Sárközy Tamás, ha ellentmondásosan is, ,de utat adott a vállalati önállóságnak, a vállalakozásnak, a civil gazdaság erősödésének. Volt mire építeni a tradicionálisan erős magyar civilisztikai gondolkodásnak. Fürst László, Szladits Károly, Kuncz Ödön, Nizsalovszky Endre, Beck Salamon, Szászy István, Eörsi Gyula munkái nyomán a magyar civiljog a hetvenes évek közepére szinte minden területen a nyugati országok civilisztikája által érthetö-összehasonlítható módon kiépült, alkalmassá vált - már szocialista körülmények között is - az Európai Közösség jogával való harmonizálásra.” (Sárközy, 1991, 11.) A reform eredményeire építkező, 1987-1989 közötti magyar gazdasági törvényhozást Sárközy kifejezetten mint a ,fejlett, modern piacgazdaság létrehozását célzó" folyamatot értékeli, mely a gazdasági jogi szemléletnek hála, kitört a „bezárt jogági gondolkodás” csődbe jutott keretei közül, s felismerte a külső és belső komplexitásában történő kodifikáció szükségességét: azt, hogy ,a gazdasági jog nem önálló kódexeket, hanem, mint Kuncz Ödön számtalanszor hangoztatta, elsődlegesen jogalkotási-jogalkalmazási szemléletmódot jelent. A gazdasági jogi komplex szemlélet, a jogi megoldások közgazdasági összefüggéseinek vizsgálatát a jövő magyar civilisztikája sem mellőzheti." (Sárközy, 1991, 16.)

A magyar gazdasági reform bevezetésére fél évszázad távlatából visszatekintve a változások jelentősége csak ennek tükrében mérhető fel - mint ahogy a munka nagyságrendje is, amit a magyar jogtudomány legkiválóbb képviselői, a jogalkotók s a gyakorló jogászok 1966-1989 között elvégeztek. Az ötvenedik évfordulón, eredményeik felidézésével a mai jogászság e szakmai teljesítmény előtt tiszteleg.

\section{IRODALOM}

Eörsi Gy. (1968): A gazdaságirányitás új rendszerére áttérés jogáról. Budapest: Közgazdasági és Jogi Könyvkiadó

Harmathy A. (1966): A szállítási szerződések szabályozása a gazdasági mechanizmus változása tükrében. Állam- és Jogtudomány, 9, 2, 279-293.

Kádár J. (1982): Felszólalás a szocialista brigádvezetők harmadik országos tanácskozásán. In: Kádár J.: Párt, szakszervezetek, szocializmus. Válogatás beszédekböl, cikkekböl, 1957-1982. Budapest: Népszava, 251-263. 
Kálmán Gy. (szerk.) (1979): A gazdaság jogi szabályozása. Budapest: Közgazdasági és Jogi Könyvkiadó

MSZMP (1966): A Magyar Szocialista Munkáspárt Központi Bizottságának határozata a gazdasági mechanizmus reformjáról. In: A gazdasági mechanizmus reformja. A Magyar Szocialista Munkáspárt Központi Bizottsága 1966. május 25-27-ei ülésének anyaga. Budapest: Kossuth Könyvkiadó, 5-48.

Sárközy T. (1981): Gazdaságirányitási és vállalati jog. Budapest: Tankönyvkiadó

Sárközy T. (szerk.) (1985): A gazdaság jogi alapjai, I-II. Budapest: Tankönyvkiadó

Sárközy T. (1991): Civilisztikánk a tegnap és a holnap között. Társadalmi Szemle, 10, 10-24.

Sárközy T. (2007): A szocializmus, a rendszerváltás és az újkapitalizmus gazdasági civiljoga, 1945-2005. Budapest: HVG-Orac Lap- és Könyvkiadó

Stark A. (2009): Rögös úton. Nemzetgazdaságunk rendszerváltás elötti és utáni két évtizede. Budapest: Akadémiai Kiadó

Tímár M. (1973): Gazdaságpolitika Magyarországon, 1967-1973. Budapest: Közgazdasági és Jogi Könyvkiadó

Vékás L. (1986): Szerződési rendszerünk és a Polgári Törvénykönyv első negyedszázada. In: Nagy M. (szerk.): Szerződések a népgazdaságban. Budapest: Igazságügyi Minisztérium Tudományos és Tájékoztató Főosztálya, 15-31. 